\title{
Sobornost and Totality in Georges Gurvitch's Social Law Doctrine
}

\author{
Mikhail Yu. Zagirnyak \\ Immanuel Kant Baltic Federal University, \\ 14, A. Nevskogo str., Kaliningrad, 236041, Russian Federation, \\ MZagirnyak@kantiana.ru
}

\begin{abstract}
Georges Gurvitch (1894-1965), from the 1920s to the end of his life, was solving the problem of combining unity and plurality in the justification of society. He believed that individualism and collectivism represented social processes in a limited way because they were based on the preconception that the binding power of law derives respectively from a private or corporate actor's will. Gurvitch contrasted individual law with the social one, which was intended to overcome the opposition between individualism and collectivism. Social law bases on legal sociology's assumption that social interactions as such are already legal relations. This conclusion allows Gurvitch to consider any social interaction as a source of law and to assert legal pluralism as a way of constructing society. The integrity of the latter is a condition for the mutual correlation of the multiplicity of legal regulations generated by internal social interactions into the unified structure of social law. In a holistic approach to comprehending social interactions, Gurvitch, in his Russian-language works in the émigré period, uses the philosophical-legal interpretation of sobornost to describe society's integrity. In French- and English-language works from the 1930s, Gurvitch uses the term "totality," which he learned from Marcel Mauss, to describe social integrity. This article compares sobornost and totality as variants of denoting social integrity in Gurvitch's social law doctrine. The researcher determines that Gurvitch, using the concepts of sobornost and totality, interpreted society's development differently, 1) as anti-hierarchical sobornost equality, and 2) as a hierarchical inordination of totalities. Having analyzed the peculiarities of the interpretation of sobornost and totality in Gurvitch's works, the author concludes that these concepts should be considered multilingual equivalents in denoting communal unity as sources of law, which reflect changes in the interpretation of society in Gurvitch's social law doctrine.
\end{abstract} Abroad

Keywords: Georges Gurvitch, Marcel Mauss, sobornost, totality, social law, Russian

Funding and Acknowledgement of Sources. This study is supported by the Russian Foundation for Basic Research, Project No. 19-011-00927 "The Concept of Conciliarity in the Philosophy of the Russian Emigration: a Comparative Historical Investigation".

(C) Zagirnyak M.Yu., 2021

This work is licensed under a Creative Commons Attribution 4.0 International License https://creativecommons.org/licenses/by/4.0/ 


\section{Article history:}

The article was submitted on 20.08.2020

The article was accepted on 14.10.2020

For citation: Zagirnyak M.Yu. Sobornost and Totality in Georges Gurvitch's Social Law Doctrine. RUDN Journal of Philosophy. 2021; 25 (1): 130 -138. DOI: 10.22363/2313-23022021-25-1-130-138

Georges Gurvitch (1894-1965) was a famous philosopher of the Russian Abroad, a classic of French sociology of law, who sought to ground society using a holistic philosophical approach. The opposing tendencies of individualism and collectivism, in his opinion, contribute to a limited understanding of society and make freedom and equality unequal. The meta-ideologies of liberalism and socialism offer models of society in which, respectively, either freedom over equality or equality over freedom prevails.

Restoring the parity of freedom and equality requires bridging the gap between the individual and the collective and harmonizing their relationship. Gurvitch proposes a solution to this problem in his social law doctrine, in which he uses solutions of the sociology of law proposed by Eugen Ehrlich, whom Gurvitch referred to as "one of the most significant representatives of the idea of social law" [1. P. 662 $]^{1}$. When assuming sociological expansion in the interpretation of the law 2 it is possible to re-evaluate its role in the formation and development of society.

\section{Problem Statement}

The sociological reflection allows Gurvitch to find the cause of individualism and collectivism in society. The traditional opposition between individual and society and the opposing tendencies of sociological individualism and universalism derive from individual law. Gurvitch believes that the prejudice about the individualistic nature of law leads to an erroneous interpretation of the will as the basis of the binding force of law [3. P. 46]. This leads to an understanding of collective phenomena (e.g., the state) as legal entities whose will is sanctioning the law, subordinating many individual individuals.

Gurvitch contrasts the individual with the social law, a model of harmonization of the relationship between the individual and society, attempting to go beyond their opposition. The sociologist assumes that social Unity is not necessarily formalized as a collective legal entity [3. P. 48].

The justification of the concept of social law required a different conceptual apparatus. Gurvitch needed a concept that would allow emphasizing the social whole as a source of law. As Jacques Le Goff rightly observes, Gurvitch never stopped looking for an answer on how to combine multiplicity and unity in society

\footnotetext{
${ }^{1}$ Gurvitch notes Eugen Ehrlich's significant role in developing a sociological perspective on law, i.e., treating social interactions as legal facts (Ref. [2. P. 73-74, 77-78]).

2 Any social interaction presupposes legal regulations, so the law derives from social relations (Ref. [2. P. 73-74]).
} 
[4. P. 15]. In his social law doctrine, to substantiate social unity, he used the following concepts. In his Russian-speaking emigrant period, he used the concept of sobornost. In his French- and English-speaking works, starting The Idea of Social Law, he used the concept of totality (totalité).

In this paper, the author would like to analyze the peculiarity of sobornost and totality in denoting social unity, to identify similarities and differences in the understanding of sociality, and, consequently, to establish whether these concepts are legitimately considered equivalent in Gurvitch's social law doctrine.

\section{Sobornost in Gurvitch's Social Law Doctrine}

In the philosophical periodicals of the Russian Abroad, Gurvitch presents the auto-theurgy doctrine, in which he develops Vladimir Solovyov's Unitotality ${ }^{3}$. Auto-theurgy is the disclosure of an individual's creative freedom participating in the Divine creative process or a member of creative sobornost [6. P. 281-282] $]^{4}$. Sobornost is an expression of specific consistency, organic solidary equality of all fellow Unity members [8. P. 331]. The concept of sobornost esteems individuals not as communal atoms but as indispensable personalities participating in the formation of social unity [8. P. 332]. As an expression of the interdependence of the whole and its parts, sobornost does not allow to consider the social Unity and the elements composing it as primary or secondary. The elements and the Unity are mutually supportive [8. P. 332].

Gurvitch uses sobornost to substantiate the social law idea to realize the parity of the principles of freedom and equality [8. P. 330]. An individual can be free only as an equal participant of social integrity. It is equality that ensures the coherence of all individuals, their immanence to the latter. Society is a set of coexisting collective wholes, each of which is a source of law and a participant in the relations arising on its basis [8. P. 351]. According to Gurvitch, to ensure the implementation of the principles of freedom and equality in society, anti-hierarchy is necessary. The attainment of social law is the equality of legal systems or sobornost wholes. Equal status and cohesiveness of all participating in social practices parties into a single Unity are ensured only through rejection of hierarchy. In particular, Gurvitch sees one of the League of Nations' functions in the leveling of large and small states [8. P. 344].

\footnotetext{
${ }^{3}$ Gurvitch undoubtedly used Solovyov's Unitotality doctrine to address the main task of social law - to overcome the confrontation between individualism and collectivism in the understanding of society. In an article published in 1922-1923, Gurvitch wrote that Solovyov "clearly manifests each specific moral significance as a specific individuality, which can fulfill its unique purpose only within society" [5. P. 150].

4 In this sense, as a representative of, Gurvitch continues the tradition of Russian religious philosophy. He contrasts the limitations of human reason and Divine Sophia's infinity (Ref. [7. P. 24-25]).
} 


\section{Totality and Total Social Fact in Gurvitch's Social Law Doctrine}

In the 1930s, Gurvitch enters the French intellectual circles. ${ }^{5}$. In his Franceand the consequent USA-published works on social law, Gurvitch does not use the concept of sobornost to describe social unity. In the researcher's opinion, M.V. Antonov quite rightly draws attention to the fact that Gurvitch tries to convey the principles of social law as a way of achieving sobornost, using the ideas and terminology of Western researchers in the conditions of European philosophical problems [9. P. 506].

Among the many theories and concepts of the Western philosophical and sociological tradition, Marcel Mauss' notions of total social fact (phénomène social total) and totality (totalité) were of great importance to Gurvitch's social law doctrine. These conceptions helped Gurvitch in the French and American intellectual milieu to justify law and order as an affirmation of social unity. Gurvitch mentions that he applied Marcel Mauss' notion of totality [10. P. 3, 5, 40]. In an obituary dedicated to Mauss, Gurvitch remarks on the importance of the totality concept in justifying society's development because it shows the inextricable connection of all aspects, manifestations, and levels of the latter [11].

Mauss attracted Gurvitch since he studied the sociocultural process from the position of sociocentrism [12. P. 123]. Historically, self-identity is the determination of a participating individual's place in the community. The very process of determining one's own "address" in the universe is an entry into a particular legal tradition. Recognizing legal regulations, an individual recognizes their participation in social practices as a representative of social unity. Mauss introduces the category of total social fact that shows that law forms regulations in all spheres of interactions and determines practices' specificity, including religion and the economy [13. P. 279]. Total social facts are formed from totalities - social systems that include the entire variety of practices of a specific society [13. P. 281]. For instance, North American Indian tribes, taking part in the ritual of gift-giving - potlatch, activate a total social fact - several consequences that concern all spheres of communal life - politics, economy, religion, etc. ${ }^{6}$

Using Mauss' terms totality and total social fact, Gurvitch justifies the idea of social law. Totality is social integrity formed by indispensable individual consciousnesses, not surpassing them but being immanent to them [3. P. 50]. Accordingly, social law is associated with the self-integration of active totality [3. P. 52] or the formation of a total social fact [14. P. 1].

${ }^{5}$ In 1929 he moved to France. In 1931 at the Sorbonne, he defended his doctoral thesis The Idea of Social Law (L'idée du droit social). The author of the article cites Gurvitch's work in the 2004 translation [3]. In 1932 Gurvitch habilitated himself in the Sorbonne with Modernity and the Idea of Social Law (Le temps présent et l'idée du droit social).

${ }^{6}$ Mauss writes about the spatial orientation of tribes [12. P. 64-107]. A hamlet acquires an "address" thanks to religion and magic, a final spatial orientation that determines all social interactions, algorithms, and regulations. 
Any collective formation is a totality producing a social law [3. P. 79]. The resulting set of totalities can coexist according to the principle of inordination integration, which "implies active participation and imposes obligations without subordinating the Unity members as disparate and static elements" [3. P. 57]. The totalities of more specified and defined communities enter into the composition of less specialized ones, playing the role of clarifying regulations in the proposed legal prescription, or at least not contradicting the established rules [3. P. 141-142].

By asserting the principle of inordination, Gurvitch thus rejects the antihierarchism of the sobornost model of public development. The coexistence of total social facts in a hierarchy does not violate the equality required for social unity. Due to hierarchy, an individual retains freedom of creativity under the conditions of equality of total social facts and receives the opportunity to self-identify as a participant in them and use the regulations they offer for self-actualization.

The development of society is a process of the emergence of total social facts and their harmonization into a unified law system. Individuals have the opportunity to shape and participate in their totality, offering new regulations for social interactions and new algorithms for the achievement of creative freedom. Therefore, any individual is aware of being a participant of society, an element of it. From Gurvitch's point of view, society's development is a path of legal pluralism under social law.

\section{Conclusion}

Gurvitch uses the concepts of sobornost and totality to justify society as a Unity, which, forming itself, expresses the separation from the rest of being in the form of law. Law is a way of creating and developing social location and defining its boundaries: the sphere of any society's reality ends where the legal system relevant in its conditions ceases to operate ${ }^{7}$. In Gurvitch's social law doctrine, sobornost and totality allow us to form a view of social dynamics beyond the opposition of individualism and collectivism.

Using sobornost and totality, Gurvitch presents two models of society, implemented in social law conditions. The first one, in the periodicals of the Russian Abroad, is the anti-hierarchical model of sobornost wholes. The second one, in the French- and English-language works, is the hierarchical model of the inordination of totalities. The main difference between the models lies in forming a society and, accordingly, the law system.

In the Russian Abroad's intellectual milieu, Gurvitch, proceeding from the Solovyov's idea of Unitotality, forms the auto-theurgy doctrine, according to which every individual is free only as a member of divine creation, an equal participant of living sobornost. Each conciliar entity remains a participant in divine creativity only equally with the others. The fulfillment of social law is the equality of legal

\footnotetext{
${ }^{7}$ For example, U.S. criminal law does not apply to the territory of Mexico. Alternatively, traffic laws do not apply to submarine maneuvers.
} 
systems or sobornost wholes. Only when the hierarchy is abandoned are equal status and connectedness of the social practices participants into a single Unity ensured.

In the French sociological school's intellectual atmosphere, Gurvitch uses Mauss' concepts of totality and total social fact to express social unity as the source of social law. Like sobornost, totality manifests itself as a system of law, distinguishing its existence in the social sphere, and can be a separate team, a state, etc. Nevertheless, now, Gurvitch believes that hierarchy does not prevent the realization of equality but rather creates a system of identifications for totality, forming a unified social structure under which each individual has the widest possible range of variation for the realization of freedom. Hierarchy under social law maximizes the achievement of freedom.

A comparative analysis of sobornost and totality in Gurvitch's social law doctrine allows us to understand them better and to reveal the peculiarities of the sociologist's interpretation of society. The study has shown that with different strategies of the organization of society, sobornost and totality in Gurvitch's doctrine play the conceptual role allowing to overcome the duel between individualism and collectivism. The anti-hierarchism of the sobornost model of society and the hierarchism of the inordinate totality are variants of the adherence to the criterion of equality and freedom principles in the development of society. The opposing interpretations of the conditions of society's development show that Gurvitch has changed his own idea of ensuring the principle of equality.

\section{References}

[1] Gurvitch G. Teorija istochnikov prava Ojgena Erliha i ideja socialnogo prava [Eugen Ehrlich's theory of sources of law and the idea of social law]. In: Ehrlich E. Osnovopolozhenie sociologii prava [Fundamental Principles of the Sociology of Law]. St. Petersburg: Universitetskij izdatelskij konsorcium; 2011. P. 453-466. (In Russian).

[2] Zagirnyak MYu. Georges Gurvitch and Sergey Hessen on the Possibility of Forming Social Unity. Kantian Journal. 2020;39(3): 7296. DOI: 10.5922/0207-6918-2020-3-4

[3] Gurvitch G. Ideja socialnogo prava [The Idea of Social Law]. In: Gurvitch G. Filosofija $i$ sociologija prava: Izbrannye sochinenija [Philosophy and Sociology of Law: Selected Works]. St. Petersburg: Izdatelskij Dom S.-Peterb. gos. un-ta Izdatelstvo juridicheskogo fakulteta S.-Peterb. gos. un-ta; 2004. P. 41-213. (In Russian).

[4] Le Goff J. Georges Gurvitch. Le pluralisme créateur. Paris: Michalon; 2012. 128 p. (In French).

[5] Gurvitch G. Dva velichajshih russkih filosofa prava Boris Chicherin i Vladimir Solovev [Two of the Greatest Russian Philosophers of Law: Boris Tchitcherin and Vladimir Soloviev]. Pravovedenie. 2005;4: 138-164. (In Russian).

[6] Gurvitch G. Etika i religija [Ethics and Religion]. Sovremennye zapiski [Annales contemporaines]. 1926;29: 259-283. (In Russian).

[7] Belov V.N., Ivleva M.L., Nizhnikov S.A. On the possibility of christian philosophy. Journal for the Study of Religions and Ideologies. 2019;18 (52):17-30.

[8] Gurvitch G. Buduschnost demokratii [The Future of Democracy]. Sovremennye zapiski [Annales contemporaines]. 1927;32: 326-355. (In Russian).

[9] Antonov M. La théorie du droit de Georges Gurvitch et ses origines philosophiques russes. Droit et société. 2016;94(3): 503-512. DOI: 10.3917/drs.094.0503 (In French). 
[10] Gurvitch G. Le concept de structure sociale. Cahiers Internationaux de Sociologie. 1955;19: 3-44. (In French).

[11] Gurvitch G. Marcel Mauss (1873-1950). Revue de Métaphysique et de Morale. 1950;2: 223. (In French).

[12] Durkheim E., Mauss M. O nekotoryh pervobytnyh formah klassifikacii. K issledovaniju kollektivnyh predstavlenij [On Some Primitive Forms of Classification: Contribution to the Study of Collective Representations]. In: Mauss M. Obschestva. Obmen. Lichnost. Trudy po socialnoj antropologii [Society. Exchange. Personality. Transactions on social anthropology]. Moscow: KDU; 2011. P. 55-124. (In Russian).

[13] Mauss M. Opyt o dare. Forma i osnovanie obmena v arhaicheskih obschestvah [The Gift: Forms and Functions of Exchange in Archaic Societies]. In: Mauss M. Obschestva. Obmen. Lichnost. Trudy po socialnoj antropologii [Society. Exchange. Personality. Transactions on social anthropology]. Moscow: KDU; 2011. P. 135-285. (In Russian).

[14] Gurvitch G. The Spectrum of Social Time. Dordrecht: D. Reidel Publishing Company; 1964. 152 p. DOI: $10.1007 / 978-94-010-3623-8$

\title{
About the author: \\ Zagirnyak Mikhail Yu. — Ph.D., research fellow of Academia Kantiana, Institute for Humanities, Immanuel Kant Baltic Federal University, Kaliningrad, Russian Federation (e-mail: MZagirnyak@kantiana.ru). \\ Соборность и тотальность в учении Георгия Гурвича о социальном праве
}

\author{
М.Ю. Загирняк \\ Балтийский федеральный университет имени Иммануила Канта, \\ Российская Федерация, 236041, Калининград, ул. А. Невского, 14, \\ MZagirnyak@kantiana.ru
}

\begin{abstract}
Аннотация. Георгий Давидович Гурвич (1894-1965) с 20-х гг. прошлого века и до конца жизни решал задачу совмещения единства и множественности в обосновании социума. Он считал, что индивидуализм и коллективизм ограниченно представляют социальные процессы, потому что они основаны на предубеждении, что обязывающая сила права происходит соответственно из воли физического/юридического лица. Индивидуальному праву Гурвич противопоставил социальное право, которое призвано было преодолеть противоборство индивидуализма и коллективизма. Социальное право построено на допущении юридической социологии о том, что социальные взаимодействия как таковые уже являются правовыми отношениями. Это решение позволяет Гурвичу рассматривать любые социальные взаимодействия как источник права и утверждать правотворческий плюрализм как способ конструирования социума. Целостность социума является условием взаимной корреляции множества правовых регламентаций, порождаемых социальными взаимодействиями внутри него, в единую структуру социального права. В условиях целостного подхода в понимании социальных взаимодействий Гурвич в русскоязычных работах эмигрантского периода использует философскоправовую трактовку соборности для характеристики целостности социума. Во франкои англоязычных работах с 30-х гг. прошлого века Гурвич для обозначения социальной целостности использует термин «тотальность», которое почерпнул у Марселя Мосса.
\end{abstract}


В статье произведен сравнительный анализ соборности и тотальности как вариантов обозначения социальной целостности в учении Гурвича о социальном праве. Было установлено, что Гурвич, используя понятия «соборность» и «тотальность», по-разному трактовал развитие социума: 1) как антииерархичное соборное равенство; 2) как иерархичную инординацию тотальностей. Проанализировав особенности трактовки соборности и тотальности в работах Гурвича, я пришел к выводу, что эти понятия следует считать разноязычными эквивалентами в обозначении социальной целостности как источников права, которые отображают изменения в трактовке общества в учении Гурвича о социальном праве.

Ключевые слова: Георгий Гурвич, Марсель Мосс, соборность, тотальность, социальное право, русское зарубежье

Информация о финансировании и благодарности. Исследование выполнено при поддержке РФФИ, проект № 19-011-00927, «Концепт соборности в философии русского зарубежья: сравнительно-исторический анализ».

\section{История статьи:}

Статья поступила 20.08.2020

Статья принята к публикации 14.10.2020

Для цитирования: Zagirnyak M.Yu. Sobornost and Totality in Georges Gurvitch's Social Law Doctrine // Вестник Российского университета дружбы народов. Серия: Философия. 2021. T. 25. № 1. C. 130-138. DOI: 10.22363/2313-2302-2021-25-1-130-138

\section{Список литературы}

[1] Гурвич Г.Д. Теория источников права Ойгена Эрлиха и идея социального права // Эрлих О. Основоположение социологии права. СПб. : Университетский издательский консорциум, 2011. С. 453-466.

[2] Загирняк М.Ю. Г.Д. Гурвич и С.И. Гессен о возможности формирования социального единства // Кантовский сборник. Т. 39. № 3. С. 72-96. DOI: 10.5922/0207-69182020-3-4

[3] Гурвич Г.Д. Идея социального права // Гурвич Г.Д. Философия и социология права: Избранные сочинения. СПб. : Издательский Дом С.-Петерб. гос. ун-та, Издательство юридического факультета С.-Петерб. гос. ун-та, 2004. С. 41-213.

[4] Le Goff J. Georges Gurvitch. Le pluralisme créateur. Paris : Michalon, 2012. 128 p.

[5] Гурвич Г.Д. Два величайших русских философа права: Борис Чичерин и Владимир Соловьев // Известия высших учебных заведений. Правоведение. 2005. № 4. C. $138-164$.

[6] Гурвич Г.Д. Этика и религия // Современные записки. 1926. Кн. 29. С. 259-283.

[7] Belov V.N., Ivleva M.L., Nizhnikov S.A. On the possibility of Christian philosophy // Journal for the Study of Religions and Ideologies. 2019. Vol. 18. № 52. P. 17-30.

[8] Гурвич Г.Д. Будущность демократии // Современные записки. 1927. Кн. 32. С. 326 355.

[9] Antonov M. La théorie du droit de Georges Gurvitch et ses origines philosophiques russes // Droit et société. 2016. № 94 (3). P. 503 - 512. DOI: 10.3917/drs.094.0503

[10] Gurvitch G. Le concept de structure sociale // Cahiers Internationaux de Sociologie. 1955. Vol. 19. P. 3-44.

[11] Gurvitch G. Marcel Mauss (1873-1950) // Revue de Métaphysique et de Morale. 1950. № 2. P. 223. 
[12] Дюркгейм Э., Мосс М. О некоторых первобытных формах классификации. К исследованию коллективных представлений // Мосс М. Общества. Обмен. Личность. Труды по социальной антропологии. М. : КДУ, 2011. С. 55-124.

[13] Мосс М. Опыт о даре. Форма и основание обмена в архаических обществах // Мосс М. Общества. Обмен. Личность. Труды по социальной антропологии. М. : КДУ, 2011. C. $135-285$.

[14] Gurvitch G. The Spectrum of Social Time. Dordrecht : D. Reidel Publishing Company, 1964. 152 p. DOI: $10.1007 / 978-94-010-3623-8$

\section{Сведения об авторе:}

Загирняк Михаил Юрьевич — кандидат философских наук, научный сотрудник, Академия Кантианы Института гуманитарных наук Балтийского федерального университета им. Иммануила Канта, Калининград, Россия (e-mail: MZagirnyak@kantiana.ru). 